\title{
Hydrochemical evaluation of water resources and human impacts on an urban karst system, Jordan
}

\author{
Julian Xanke ${ }^{1} \cdot$ Anna Ender $^{2} \cdot$ Felix Grimmeisen $^{3} \cdot$ Nadine Goeppert $^{1} \cdot$ Nico Goldscheider $^{1}$
}

Received: 17 December 2019 / Accepted: 24 April 2020 / Published online: 5 June 2020

(C) The Author(s) 2020

\begin{abstract}
Urban karst aquifers are threatened by anthropogenic activities, especially in semiarid developing countries. Recent watersampling campaigns assessed the extent of groundwater-quality impairment in the Wadi Shueib in Jordan by a comprehensive hydrogeological and hydrochemical characterization of groundwater, wastewater, and imported water with its endmembers Lake Tiberias, Yarmouk River and Mukheiba wellfield. The results of a ternary mixing model with the mass ratios of $\mathrm{Cl}^{-} / \mathrm{Br}^{-}$and $\mathrm{Ca}^{2+} / \mathrm{Mg}^{2+}$ indicate that Lake Tiberias and Yarmouk River provide most of the imported water at the time of sampling in 2017 and Mukheiba wellfield provided minor amounts. The similarity in seasonal variations of $\mathrm{Br}^{-}$concentrations in the springs and the imported water revealed that imported water has generally a greater impact on groundwater than wastewater. However, the $\mathrm{Br}^{-}$concentrations also showed that the spatial wastewater impact is more visible towards urbanized areas due to increased infiltration of pollutants. The analysis of historical data series demonstrated the long-term urban impact on groundwater by an electrical conductivity increase over several decades, particularly since the mid-1990s, which is related to a doubling of Jordan's population since that time and the associated urban growth. In this context, increased chloride and sulfate concentrations are noticeable due to the increased impact of more highly mineralized imported water and wastewater and decreasing recharge of low-mineralized rainwater. This study showed the hydrochemical differences in the Wadi Shueib groundwater system and serves as an example for the spatial and long-term response of karst aquifers to anthropogenic, seasonally variable input of imported water and wastewater.
\end{abstract}

Keywords Karst $\cdot$ Hydrochemistry $\cdot$ Urban groundwater $\cdot$ Semi-arid $\cdot$ Jordan

\section{Introduction}

Karst aquifers can be found worldwide and often constitute the most important source of drinking water, especially in

Electronic supplementary material The online version of this article (https://doi.org/10.1007/s10040-020-02174-2) contains supplementary material, which is available to authorized users.

Julian Xanke

julian.xanke@kit.edu

$1 \quad$ Karlsruhe Institute of Technology (KIT), Institute of Applied Geosciences (AGW), Division of Hydrogeology, Kaiserstr. 12, 76131 Karlsruhe, Germany

2 Karlsruhe Institute of Technology (KIT), Project Management Agency Karlsruhe (PTKA), Hermann-von-Helmholtz-Platz 1, 76344 Eggenstein-Leopoldshafen, Germany

3 SEBA Hydrometrie GmbH \& Co. KG, Gewerbestraße 61 A, Kaufbeuren D-87600, Germany semiarid to arid regions (Goldscheider et al. 2019). Their natural heterogeneity and duality of discharge pattern make them particularly vulnerable to contamination, which is challenging in terms of groundwater protection and management. The anthropogenic-induced impact on groundwater quality is becoming increasingly apparent on urbanized karst aquifers. Due to an often-dilapidated water infrastructure, pollutants easily reach the groundwater through fissures and swallow holes and are quickly transported via karst conduits to springs or wells, often along preferential flow paths (Ford and Williams 2007). These water-quality impairments are often observed locally through short-term contamination, usually after rainfall events, but also become visible in the long-term and include a large number and variety of contaminants (Ascott et al. 2016; Zemann et al. 2014; Grimmeisen et al. 2016). However, unwanted water losses in sewer and drinking water supply networks also affect groundwater resources through recharge (Tubau et al. 2017), often with higher rates than in natural settings (Lerner 2002). Therefore, karst aquifer 
management requires a profound knowledge of the natural hydrogeological and hydrochemical setting and the spatial and temporal degree of the anthropogenic impairment.

Many karst aquifers in semiarid areas of the Middle East are affected by these groundwater impairments caused by urbanisation. Numerous studies have attempted to assess the anthropogenic effects by using various indicators such as stable isotopes, chloride, nitrate, indicator bacteria e.g. Escherichia coli (E. coli) and pharmaceuticals (Schmidt et al. 2013; Doummar et al. 2014; Zemann et al. 2015; Tagar et al. 2007; Anayah and Almasri 2009). Some studies have estimated the proportion of wastewater in groundwater (Schmidt et al. 2013; Grimmeisen et al. 2017). In this context, mixing models are commonly applied for quantifying the source contributions to a mixture (Vázquez-Suñé et al. 2010), based on the different chemical signature of the endmembers. Here, various concepts are available such as endmember mixing analysis (EMMA), mixing ratios or lumped models (Christophersen and Hooper 1992; Hooper 2003; Barthold et al. 2011; Jurgens et al. 2014; Peng et al. 2016; Tubau et al. 2014), which allow an estimation of the mixing ratios for nonconservative dissolved substances whose concentration is known in the endmembers.

Although there are many studies using $\mathrm{Cl}^{-}$as conservative tracer, it is controversial since a solution's $\mathrm{Cl}^{-}$concentrations may change due to unaccounted $\mathrm{Cl}^{-}$sources such as dissolution/precipitation of natural salts or anthropogenic salts, e.g. fertilizers (Horner et al. 2017). Sources for $\mathrm{Cl}^{-}$in nature are atmospheric deposition, rock weathering, and basin brines (Lax et al. 2017). In unimpaired karst aquifers, chloride concentrations of groundwater are controlled by the chloride concentration of local precipitation, if no evaporitic minerals such as halite are present (Schmidt et al. 2013). However, the input of anthropogenic salts (e.g. fertilizers or deicing agents) in groundwater resources can strongly modify chloride concentrations (Horner et al. 2017); therefore, $\mathrm{Cl}^{-} / \mathrm{Br}^{-}$ratios are seen to be more effective as environmental tracer, especially when endmembers have strongly contrasting compositions (Horner et al. 2017). A large proportion of $\mathrm{Br}^{-}$in groundwater originates from human activities, like biomass burning, application of antiknock additives to gasoline and the usage of agricultural chemicals (Davis et al. 2004).

The karst aquifer system below the city As-Salt in the Wadi Shueib in Jordan is known for being affected by city effluents from imported freshwater supply and sewer network leakages, which contribute $30-64 \%$ to recharge, whereby $5-18 \%$ is wastewater (Grimmeisen et al. 2017). These estimates are based on ternary mixture calculations using stable isotope ratios $\left(\delta \mathrm{D}_{\mathrm{H} 2 \mathrm{O}}\right.$ and $\left.\delta^{18} \mathrm{O}_{\mathrm{H} 2 \mathrm{O}}\right)$ of water and chloride $\left(\mathrm{Cl}^{-}\right)$but showed the need for further investigations of the water chemistry of imported water and its endmembers as well as an overall hydrochemical characterization of the Wadi Shueib groundwater system. Likewise, the use of $\mathrm{Cl}^{-}$as a conservative tracer in this system was considered probably to be not effective.

This study provides new insights from recent watersampling surveys and the analysis of historical hydrochemical data series. The central research questions deal with (1) the subdivision of the endmembers of the imported water, namely Lake Tiberias, Yarmouk River and Mukheiba wellfield, and the hydrochemical evolution of the imported water along the open King Abdullah Canal supply system, (2) the assessment of the impact of leakages from imported freshwater and wastewater on the groundwater system of Wadi Shueib and (3) the hydrochemical long-term evolution of groundwater chemistry in recent decades in the context of population growth and urbanization. The results of this study form the basis for the development of adapted rehabilitation and protection concepts to improve water supply and wastewater management in the urban karst area of the Wadi Shueib.

\section{Study area}

\section{Hydrogeological setting}

The river basin of the Lower Jordan Valley (LJV) stretches from Lake Tiberias in the north to the Dead Sea in the south and is characterized by an intense relief from $1,100 \mathrm{~m}$ above sea level (m asl) at the lateral mountains to $-434 \mathrm{~m}$ asl at the Dead Sea (ISRAMAR 2019). On the western slopes of the Transjordanian Mountains a network of east-west oriented wadis shape the drainage system of the area, whereby the Wadi Shueib represents one subcatchment (Fig. 1c). The study area includes the upper part of Wadi Shueib (Fig. 1d), where a semiarid Mediterranean climate with short rainy winters and long dry summers is prevailing. The annual rainfall ranges between about 500 and $700 \mathrm{~mm}$ (Grimmeisen et al. 2016) and often occurs in the form of intense and short precipitation events.

The rock formations of the Upper Cretaceous Ajloun Group form the geological structure of the area and include three major aquifer systems - Naur (A1/2), Hummar (A4) and Wadi Es-Sir (A7). These aquifers are mainly composed of dolomitic limestone (A1/2), crystalline limestone and dolomite (A4) and hard, massive karstified limestone (A7). They are separated by the Fuheis (A3) and Shueib (A5/6) formations, which consist of dolomitic thinly bedded limestones or siltstones, interbedded with thin layers of marls (Fig. 1d; Werz 2006), and are described as leaky aquitards. Furthermore, numerous vertical fractures and fault zones within the Fuheis and the Shueib Formations, caused by intensive compressive tectonics, result in vertical displacements and hydraulic connectivity between aquifers (Fig. 2; Werz 2006).

In the northern part of the Wadi Shueib about 27 registered springs discharge from the Upper Cretaceous-aquifer complex 

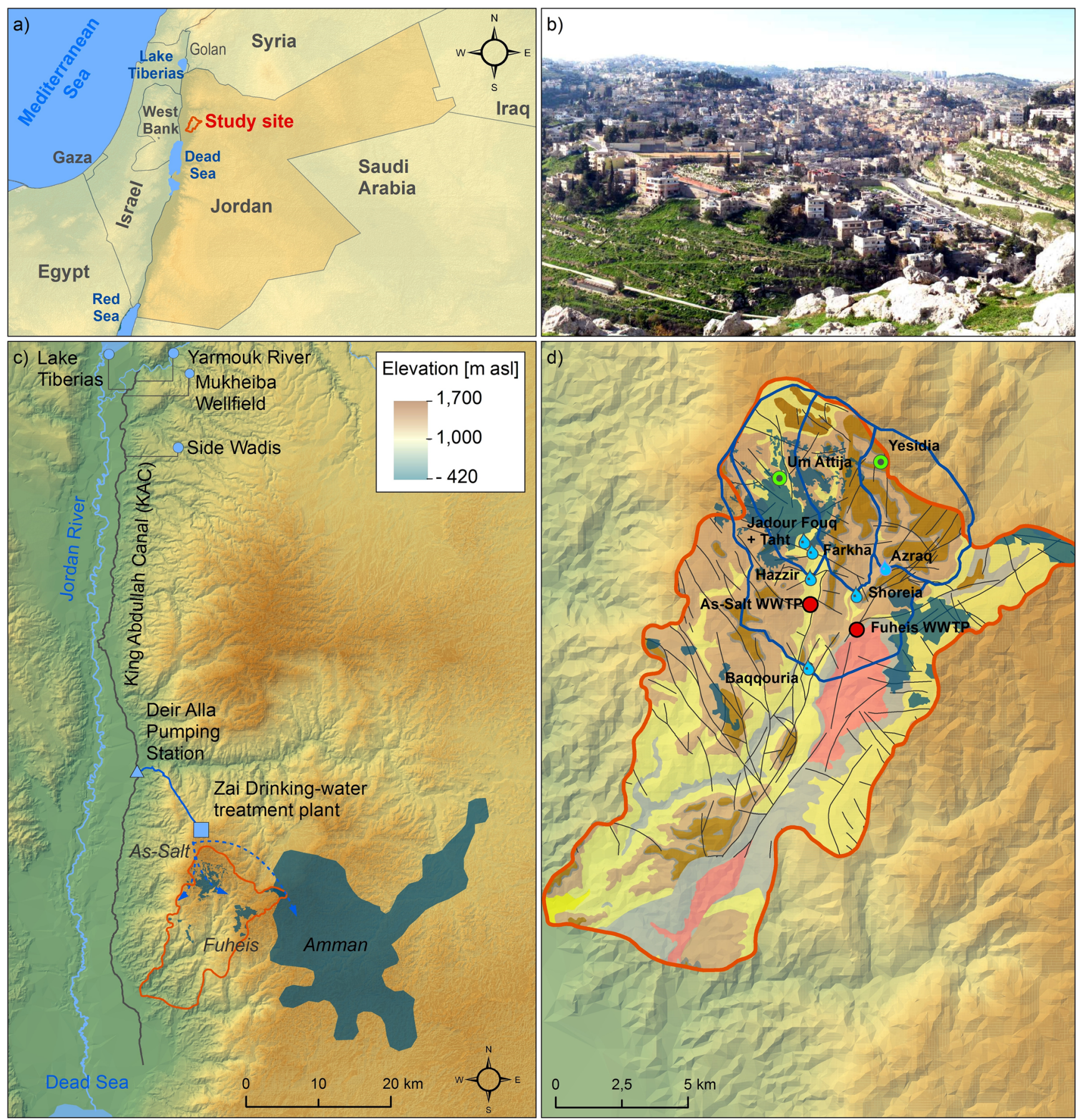

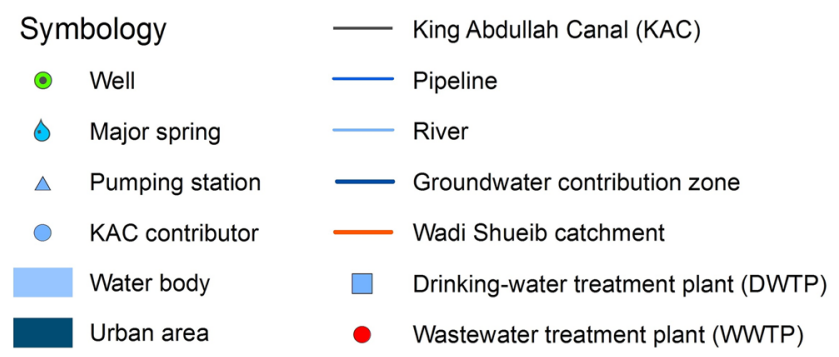

Fig. 1 a Geographical location of Jordan. b View at the city As-Salt in the Wadi Shueib catchment. $\mathbf{c}$ The location of the Wadi Shueib and its water import route with the most important contributing water sources. $\mathbf{d}$ The

\section{Geology}

\begin{tabular}{|l|c|c|c|}
\hline & Quaternary deposits & A3-6 & Fuheis/Hummar/Shueib \\
\hline B2b & Al Hisa Phosphorite & A1/2 & Na'ur Limestone \\
\hline B2a & Amman Silicified Limestone & $\mathrm{K}$ & Kurnub Sandstone \\
\hline B1 & Wadi Umm Ghudran & & Fault \\
& A7 & Wadi as Sir Limestone &
\end{tabular}

geological setup of Wadi Shueib, the location of two wells and the major springs with their approximate groundwater contribution zones 


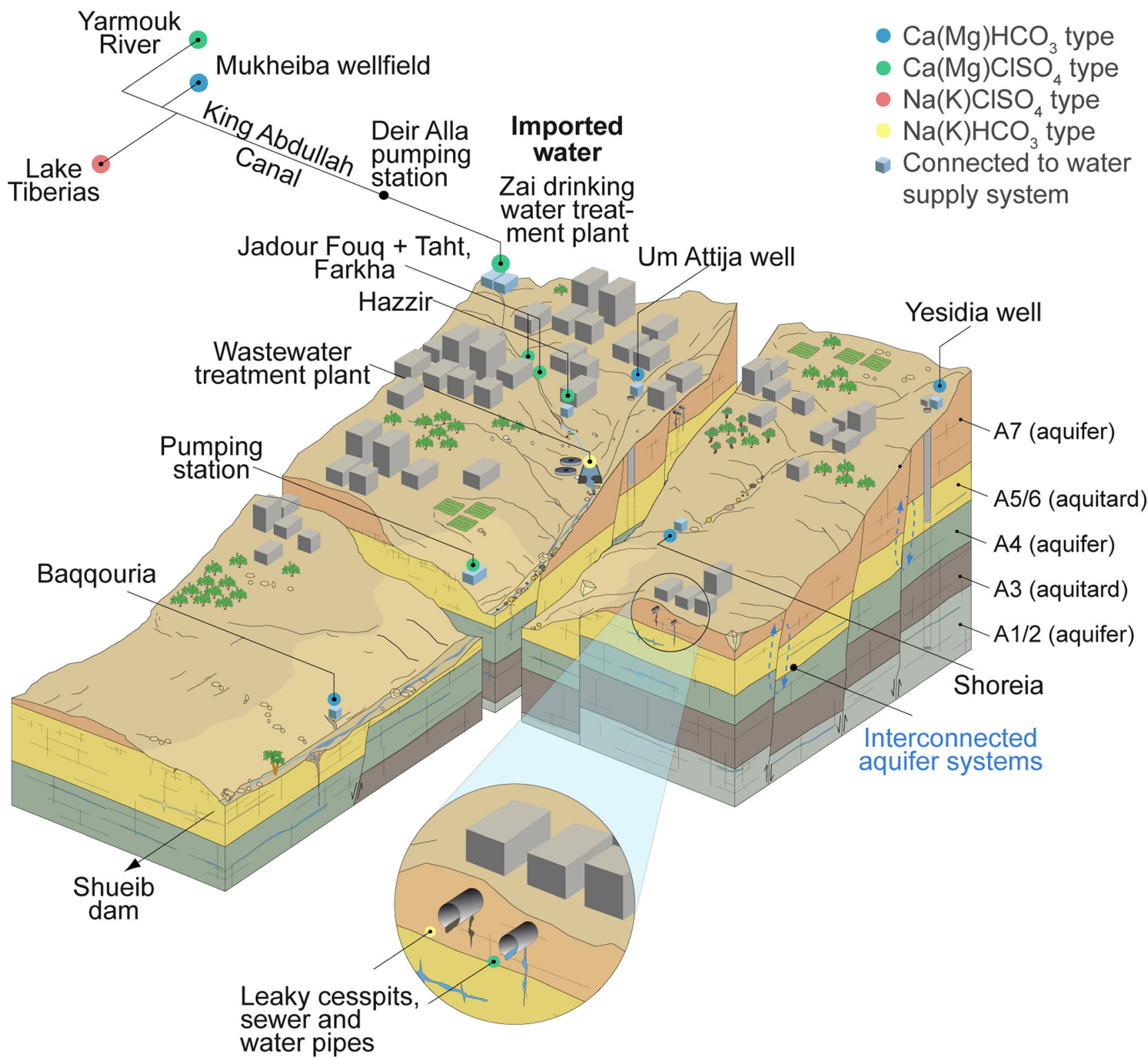

Fig. 2 Conceptual geological block diagram of the upper Wadi Shueib with the location of the Jadour Fouq and Taht, Farkha, Hazzir, Baqqouria and Shoreia springs, the Um Attija and Yesidia wells and the As-Salt wastewater treatment plant

with an average total quantity of about 11.3 million $\mathrm{m}^{3} /$ year (Margane et al. 2002), but very different and varying individual flow rates (Riepl 2013). Most of the documented springs are above $500 \mathrm{~m}$ elevation and are either attributed to the A7, the A1/2 or the A4 aquifer (Werz 2006; Riepl 2013; Margane et al. 2010). The latter aquifer, however, is of minor significance. Most important springs are Hazzir, Shoreia, Azraq and Baqqouria. All four springs play an important role in the local water supply while local farmers mainly use smaller springs such as Jadour (Taht and Fouq) and Farkha for agricultural irrigation (Riepl 2013). In 2012, the Hazzir spring was disconnected from the drinking water supply due to frequent contamination problems and weekly fluctuations, with bacterial levels increasing on weekends due to leakages and intermittent water supply (Grimmeisen et al. 2016), which generally occur subsequent to rainfall events during the winter season (Margane et al. 2010). Perennial surface runoff in the Wadi Shueib originates partly from the Baqqqouria spring and partly from treated wastewater-release from the treatment plant of As-Salt with an accumulated average annual baseflow of about 3-8 million $\mathrm{m}^{3}$ (Margane et al. 2010; Kuntz 2003). A conceptual geological model of the upper Wadi Shueib catchment and the location of the sampled springs and wells are shown in Fig. 2.

The urban areas in Wadi Shueib shown in Fig. 1d cover about $17.7 \mathrm{~km}^{2}$, of which $10 \mathrm{~km}^{2}$ are located in the catchments 
(groundwater contribution zones) of the major springs. The Baqqqouria spring catchment $\left(71.7 \mathrm{~km}^{2}\right)$ is covered by about $14 \%$ with urban areas, the Hazzir catchment by $37 \%$ and the Shoreia and Azraq catchments by 14.7 and $0.1 \%$ respectively.

To meet the water demand of the upper Wadi Shueib and its communities, additional water is imported from the King Abdullah Canal, which generally supplies water for irrigation purposes to the Lower Jordan Valley and also freshwater to the cities of Amman and As-Salt. From Deir Alla (in the Lower Jordan Valley) water is pumped over an elevation of more than $1000 \mathrm{~m}$ to the Zai drinking-water treatment plant (DWTP), where it is treated and fed to the freshwater distribution system (Fig. 1c). Water from King Abdullah Canal consists of a mixture of different sources, namely Lake Tiberias, Yarmouk River and Mukheiba wellfield (Fig. 1c) and, to a lesser extent, several side wadis, i.e. the dry valleys that normally carry water temporarily and often only after heavy or long-lasting rainfall. The different fractions of the water undergo strong variations. From a total water amount of 100-200 million $\mathrm{m}^{3}$ /year, delivered by the King Abdullah Canal, 30-50\% through the year originate from Lake Tiberias with the higher proportions during the dry season from April to October. More precise numbers were not available.

\section{Methodology}

\section{Sampling and analysis}

Sampling campaigns were conducted in November 2017 and April 2018. In the course of the first campaign, samples were taken at points that are relevant for the water cycle of As-Salt, including five karst springs, two wells, treated wastewater at the As-Salt wastewater treatment plant (WWTP) and Fuheis WWTP, treated imported water at Zai DWTP and water mains in As-Salt. Furthermore, the Lake Tiberias, the Yarmouk River and one Mukheiba well as well as the King Abdullah Canal at three different locations were sampled (Fig. 1c). In 2018, samples were taken at the five karst springs (Hazzir, Baqqouria, Shoreia, Farkha and Jadour Fouq), two wells (Yesidia and Um Attija), mains water and at two locations of the King Abdullah Canal. For comparison, historical hydrochemical data were obtained from the database of the Ministry of Water and Irrigation (MWI) including the Azraq and the Jadour Taht springs.

Water samples for major ions analysis were filtered with cellulose acetate membrane filters $(0.45 \mu \mathrm{m})$ and collected in high-density polyethylene bottles $(30 \mathrm{ml}$; Rixius AG, Mannheim, Germany). Water samples for stable isotopes analysis were filtered with above-mentioned filters, but were collected in brown glass bottles $(4 \mathrm{ml}$; Carl Roth $\mathrm{GmbH}+\mathrm{Co}$. KG, Karlsruhe, Germany). Samples for cation analyses were stabilized with nitric acid, and all samples were stored in a fridge before they were transported to Germany for analysis. The cations $\left(\mathrm{Ca}^{2+}, \mathrm{Mg}^{2+}, \mathrm{Na}^{+}\right.$and $\left.\mathrm{K}^{+}\right)$were analyzed with an atomic absorption spectrometer Shimadzu AA-7000. The anions $\mathrm{SO}_{4}{ }^{2-}, \mathrm{NO}_{3}{ }^{-}$and $\mathrm{Cl}^{-}$were measured with ion chromatography (Dionex ICS-2100, Thermo Fisher Scientific Inc., Waltham, MA, USA). $\mathrm{HCO}_{3}{ }^{-}$and $\mathrm{CO}_{3}{ }^{2-}$ were directly determined on-site by using an alkalinity test $(111,109$, Merck Millipore, Billerica, MA, USA). The $\mathrm{pH}$, electrical conductivity (EC) and temperature were measured in situ with field equipment (WTW). Oxygen-18 and Deuterium were analyzed using a spectroscopic water isotope analyzer (Los Gatos Research, USA). Water isotope signatures are reported in the delta notation $\left(\delta \mathrm{D}_{\mathrm{H} 2 \mathrm{O}}, \delta^{18} \mathrm{O}_{\mathrm{H} 2 \mathrm{O}}\right)$ in $\%$, relative to $\mathrm{V}$-SMOW (Vienna-Standard Mean Ocean Water): $\delta=\left(R_{\text {sample }}\right.$ $\left./ R_{\text {standard }}-1\right) \times 1000 \%$, with the ratio $R$ of ${ }^{2} \mathrm{H} /{ }^{1} \mathrm{H}$ or ${ }^{18} \mathrm{O} /{ }^{16} \mathrm{O}$ in the sample and standard, respectively. Replicate reproducibility was generally better than $\pm 0.5 \%$ for $\delta \mathrm{D}_{\mathrm{H} 2 \mathrm{O}}$ and \pm $0.08 \%$ ofor $\delta^{18} \mathrm{O}_{\mathrm{H} 2 \mathrm{O}}$.

\section{Endmember mixing}

Two different mixing analyses were conducted to assess (1) the different fractions $(f)$ contributing to the groundwater in Wadi Shueib, down-gradient of As-Salt and (2) the fractions contributing to the imported water for As-Salt, conveyed by the King Abdullah Canal. The first case is based on the study of Grimmeisen et al. (2017) who used dual water isotope endmember mixing calculations as well as ternary mixing calculations to assess the mixing proportions within the urban water cycle of As-Salt. Due to random sampling, the mixing model is not representative for the entire hydrological year.

Three main types of water (endmembers) contribute to the impacted groundwater: (1) groundwater, (2) wastewater from sewers and (3) mains water from the distribution network. However, mains water itself is a mixture of groundwater from the Wadi Shueib aquifers and the imported water from Zai DWTP. Therefore, the three-component mixing analysis, exemplarily for the tracer combination $\mathrm{Cl}^{-}$and $\mathrm{Cl}^{-} / \mathrm{Br}^{-}$mass ratio, can be written as:

$$
\begin{aligned}
& 1=f_{\mathrm{GW}}+f_{\text {import }}+f_{\text {waste }} \\
& \begin{aligned}
\frac{\left[\mathrm{Cl}^{-}\right]_{\text {Spring }}}{\left[\mathrm{Br}^{-}\right]_{\text {Spring }}}= & f_{\mathrm{GW}} \cdot \frac{\left[\mathrm{Cl}^{-}\right]_{\mathrm{GW}}}{\left[\mathrm{Br}^{-}\right]_{\mathrm{GW}}}+f_{\text {import }} \cdot \frac{\left[\mathrm{Cl}^{-}\right]_{\text {import }}}{\left[\mathrm{Br}^{-}\right]_{\text {import }}} \\
& +f_{\text {waste }} \cdot \frac{\left[\mathrm{Cl}^{-}\right]_{\text {Waste }}}{\left[\mathrm{Br}^{-}\right]_{\text {Waste }}} \\
{\left[\mathrm{Cl}^{-}\right]_{\text {Spring }}=} & f_{\mathrm{GW}} \cdot\left[\mathrm{Cl}^{-}\right]_{\mathrm{GW}}+f_{\text {import }} \cdot\left[\mathrm{Cl}^{-}\right]_{\text {import }} \\
& +f_{\text {waste }} \cdot\left[\mathrm{Cl}^{-}\right]_{\text {waste }}
\end{aligned}
\end{aligned}
$$

For the endmember groundwater $f_{\mathrm{GW}}$, the hydrochemical signature of the Yesidia well $\left(f_{\mathrm{GW}}=1 ; \mathrm{Cl}^{-}: 57 \mathrm{mg} / \mathrm{L} ; \mathrm{Cl}^{-} / \mathrm{Br}^{-}\right.$: 
116) was chosen because the well is located up-gradient of the city of As-Salt and pumps from a depth of about $270 \mathrm{~m}$; therefore, this water is seen as unimpaired groundwater. For the imported water $f_{\text {import }}$, the sample from Zai DWTP $\left(f_{\text {import }}=1\right.$; $\mathrm{Cl}^{-}: 158 \mathrm{mg} / \mathrm{L} ; \mathrm{Cl}^{-} / \mathrm{Br}^{-}: 100$ ) was used, and for wastewater $f_{\text {waste }}$ the average values of the water sampled at the As-Salt WWTP and Fuheis WWTP $\left(f_{\text {waste }}=1 ; \mathrm{Cl}^{-}: 217 \mathrm{mg} / \mathrm{L} ; \mathrm{Cl}^{-} /\right.$ $\mathrm{Br}^{-}$: 194) were assumed to be representative.

The second case comprises the ternary mixing model for the imported water, conveyed by the King Abdullah Canal, assuming that the water fractions from the Yarmouk River $\left(f_{\text {Yar }}\right)$, the Mukheiba wellfield $\left(f_{\text {Muk }}\right)$ and the Lake Tiberias $\left(f_{\text {Tib }}\right)$ are the only contributors. Although there are small water contributions from side wadis, they are seen to be negligible $(<1 \%$ of the total discharge). The mixing model is defined by using the mass ratios of $\mathrm{Cl}^{-} / \mathrm{Br}^{-}$and $\mathrm{Ca}^{2+} / \mathrm{Mg}^{2+}$.

$$
\begin{aligned}
& 1=f_{\text {Yar }}+f_{\text {Muk }}+f_{\text {Tib }} \\
& \frac{\left[\mathrm{Cl}^{-}\right]_{\text {import }}}{\left[\mathrm{Br}^{-}\right]_{\text {import }}}=f_{\text {Yar }} \cdot \frac{\left[\mathrm{Cl}^{-}\right]_{\mathrm{Yar}}}{\left[\mathrm{Br}^{-}\right]_{\mathrm{Yar}}}+f_{\mathrm{Muk}} \cdot \frac{\left[\mathrm{Cl}^{-}\right]_{\mathrm{Muk}}}{\left[\mathrm{Br}^{-}\right]_{\mathrm{Muk}}} \\
& +f_{\text {Tib }} \cdot \frac{\left[\mathrm{Cl}^{-}\right]_{\text {Tib }}}{\left[\mathrm{Br}^{-}\right]_{\text {Tib }}} \\
& \frac{\left[\mathrm{Ca}^{2+}\right]_{\text {import }}}{\left[\mathrm{Mg}^{2+}\right]_{\text {import }}}=f_{\text {Yar }} \cdot \frac{\left[\mathrm{Ca}^{2+}\right]_{\mathrm{Yar}}}{\left[\mathrm{Mg}^{2+}\right]_{\mathrm{Yar}}}+f_{\mathrm{Muk}} \cdot \frac{\left[\mathrm{Ca}^{2+}\right]_{\mathrm{Muk}}}{\left[\mathrm{Mg}^{2+}\right]_{\mathrm{Muk}}} \\
& +f_{\text {Tib }} \cdot \frac{\left[\mathrm{Ca}^{2+}\right]_{\text {Tib }}}{\left[\mathrm{Mg}^{2+}\right]_{\text {Tib }}}
\end{aligned}
$$

As described in the preceding, imported water is represented by the sample from Zai DWTP $\left(f_{\text {import }}=1 ; \mathrm{Cl}^{-} / \mathrm{Br}^{-}: 100\right.$; $\left.\mathrm{Ca}^{2+} / \mathrm{Mg}^{2+}: 1.45\right)$.

\section{Results and discussion}

\section{Stable hydrogen and oxygen isotope composition}

The isotopic composition of the water samples from November 2017 show that the imported water (King Abdullah Canal and Zai DWTP) is a mixture of the three endmembers Lake Tiberias, Yarmouk River and Mukheiba wellfield, which are characterized by strongly different isotopic signatures, particularly of the Mukheiba well $\left(\delta^{18} \mathrm{O}_{\mathrm{H} 2 \mathrm{O}}=\right.$ $-6.2 \%$ and $\delta \mathrm{D}=-31 \% \circ)$ and Lake Tiberias $\left(\delta^{18} \mathrm{O}_{\mathrm{H} 2 \mathrm{O}}=1.3 \%\right.$ 。 and $\delta \mathrm{D}=9.5 \%$; Fig. 3 ). The isotopic signature of water from the Yarmouk River $\left(\delta^{18} \mathrm{O}_{\mathrm{H} 2 \mathrm{O}}=-4.5 \%\right.$ and $\delta \mathrm{D}=-22.7 \%$ o $)$ lies between these two. A description of the imported water by a ternary mixture model is therefore not necessary.

The springs and wells exhibit a range of $\delta^{18} \mathrm{O}$ from $-5.8 \%$ (Yesidia) to $-3.5 \%$ (Jadour Fouq) and $\delta \mathrm{D}$ from -28.1 to $-16.7 \%$ resulting in a $\delta \mathrm{D} / \delta^{18} \mathrm{O}$ slope of 4.7 , which is significantly lower than the slope of the local meteoric water line (LMWL; Bajjali 2012) and the eastern meteoric water line (EMWL; Gat and Carmi 1970). This indicates evaporation before infiltration and/or mixing processes with water of different stable isotopic composition (Karroum et al. 2017). The $\delta \mathrm{D} / \delta^{18} \mathrm{O}$ trend between the Wadi Shueib springs indicate that Shoreia and Baqqouria, which are closely related to local meteoric water, are the least affected springs, as also shown by Grimmeisen et al. (2017). With the enrichment of heavy water isotopes, the impact of the mixture with water that has undergone evaporative loss, such as the imported water from King Abdullah Canal, increases.

\section{Endmember mixing}

As shown in Fig. 3 the hydrochemical character of the water resources of Lake Tiberias, Yarmouk River and Mukheiba wellfield differ strongly. While the isotopic signature enables only the consideration of a binary mixing, the combination of mass ratios of $\mathrm{Cl}^{-} / \mathrm{Br}^{-}$and $\mathrm{Ca}^{2+} / \mathrm{Mg}^{2+}$ allows the application of a ternary mixing model (Fig. 4). Usually, in groundwater, $\mathrm{Ca}^{2+} / \mathrm{Mg}^{2+}$ ratios cannot be seen as a conservative tracer due to dissolution of carbonates, but within the King Abdullah Canal, dissolution effects are negligible. Therefore, $\mathrm{Ca}^{2+}$ $\mathrm{Mg}^{2+}$ ratios are likely to provide more reliable information than stable isotopes, which are influenced by evaporation along the King Abdullah Canal. Due to the sparse data basis, a quantitative evaluation has uncertainties, especially because the mixing ratios are subject to strong temporal variability and the values were determined by random sampling. However, the mixing model in Fig. 4 suggests that the main suppliers of imported water at the time of sampling in November 2017 are Lake Tiberias and the Yarmouk River, with a lower proportion of water from the Mukheiba wellfield. These conditions may change over the entire hydrological year.

\section{Water chemistry}

For a comparable presentation of the newly obtained data and the historical hydrochemical data and their range of occurrence, a statistical summary of the respective water sources is shown in Tables 1 and 2. The highest electrical conductivity values are found in both the WWTP and the Lake Tiberias, attributed to high $\mathrm{Na}^{+}, \mathrm{Cl}^{-}$and $\mathrm{SO}_{4}{ }^{2-}$ concentrations, whereas higher average $\mathrm{Ca}^{2+}$ values were found in the springs and wells. Average temperatures range between 17.9 and $22.6{ }^{\circ} \mathrm{C}$ with one exception for Mukheiba well 8 with a measured temperature of $45^{\circ} \mathrm{C}$. The $\mathrm{pH}$ values differ and range between 7.2 and 8.6.

The Piper diagram (Fig. 5) reveals a dominance of calcium and bicarbonate in groundwater corresponding to the prevailing limestone and dolomite. The order of abundance of the ions (in $\mathrm{mg} / \mathrm{L}$ ) in groundwater is $\mathrm{Ca}^{2+}>\mathrm{Na}^{+}>\mathrm{Mg}^{2+}>\mathrm{K}^{+}$and 
Fig. 3 Isotopic composition of regional water sources and groundwater, sampled in November 2017. The water samples from the wells, springs and the water distribution system (Mains water and King Abdullah Canal, KAC) are along a line between the Mukheiba well, the Yarmouk River and Lake Tiberias. The eastern (EMWL; Gat and Carmi 1970) and local meteoric water line (LMWL, Bajjali 2012) are shown for comparison

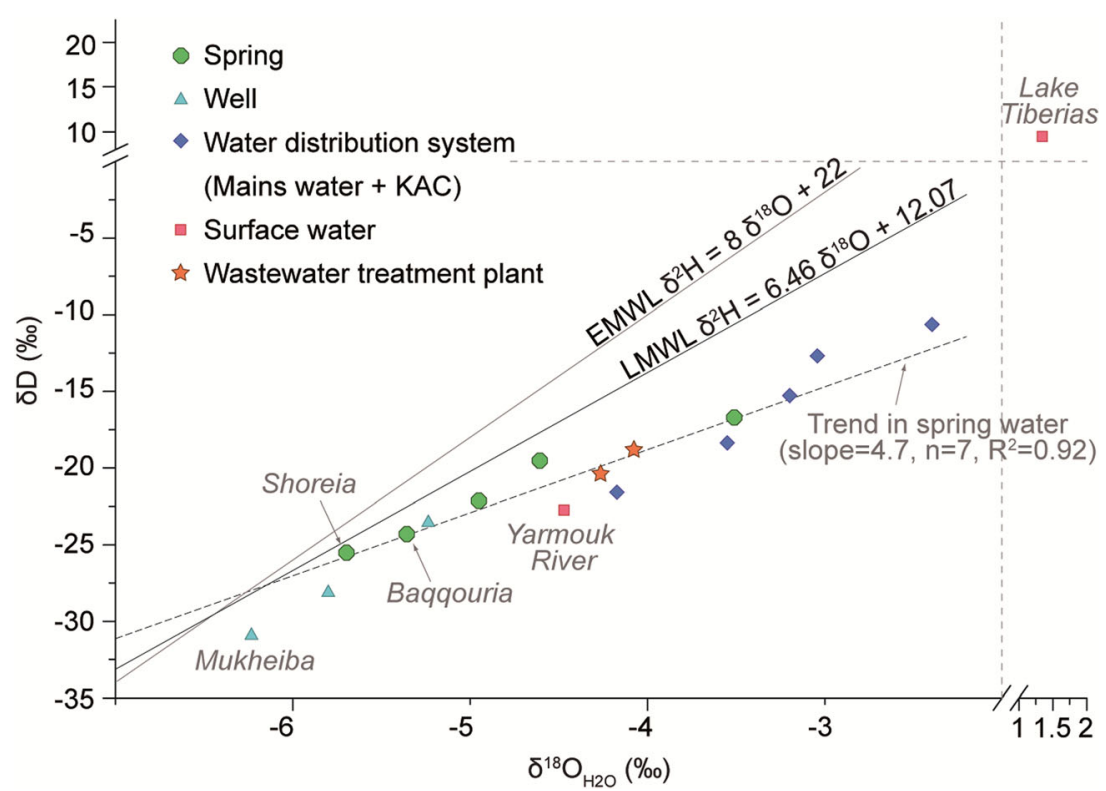

$\mathrm{HCO}_{3}{ }^{-}>\mathrm{Cl}^{-}>\mathrm{SO}_{4}{ }^{2-}>\mathrm{NO}_{3}{ }^{-}$. An electrical conductivity increase in groundwater can be observed in the following sequence: Shoreia, Azraq, Baqqouria, Yesidia, Um Attija, Farkha, Jadour Taht, Jadour Fouq and Hazzir. The different hydrochemical signatures allow them to be grouped into the upper springs (including the two wells), the lower springs and the imported water sources (Fig. 5). The lower springs are located more in rural areas, the upper springs near urban areas. High mean nitrate values can be found in Jadour Fouq, Jadour Taht, Hazzir and Farkha springs (64.4-99.8 mg/L) demonstrating their high vulnerability to contamination. Surface water (Yarmouk River, Lake Tiberias and King Abdullah Canal) and water from the WWTP is more sodium and bicarbonate dominated with a dominating order of ion abundance (in $\mathrm{mg} /$ L) of $\mathrm{Na}^{+}>\mathrm{Ca}^{2+}>\mathrm{Mg}^{2+}>\mathrm{K}^{+}$and $\mathrm{HCO}_{3}{ }^{-}>\mathrm{Cl}^{-}>\mathrm{SO}_{4}{ }^{2-}>$
$\mathrm{NO}_{3}^{-}$, whereas the WWTP samples reveal the highest $\mathrm{K}^{+}$ values and the Lake Tiberias the highest $\mathrm{Cl}^{-}$values.

The clustered pattern (Fig. 5) of the upper springs (including the two wells), the lower springs and the imported water sources is even more obvious considering a binary diagram of $\mathrm{Na}^{+}$vs. $\mathrm{SO}_{4}{ }^{2-}$ (Fig. 6). By using this parameter combination, a binary mixing between the assumed unimpaired groundwater and imported water or wastewater is expected. In addition to the Yesidia well, water from the Shoreia spring is also considered as unimpaired groundwater due to its location and hydrochemical composition. As already mentioned, the imported water supplied by the King Abdullah Canal, is a mixture of the three main contributors - the Yarmouk River, Lake Tiberias and the Mukheiba wells - and therefore originates from very heterogeneous areas. Water from Lake Tiberias exhibits high
Fig. 4 Ternary mixing model with the mass ratios of $\mathrm{Cl}^{-} / \mathrm{Br}^{-}$ and $\mathrm{Ca}^{2+} / \mathrm{Mg}^{2+}$ for the three endmembers of the imported water, the King Abdullah Canal (KAC) and the Zai drinking-water treatment plant from where the water is supplied to the Wadi Shueib. The samples were taken in November 2017

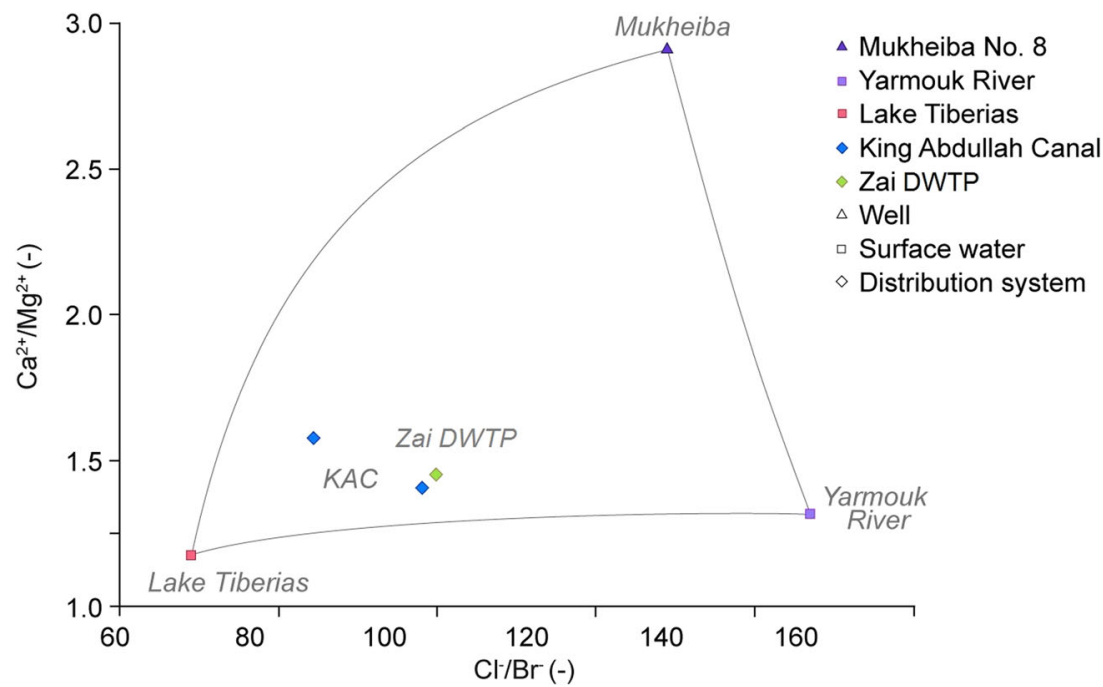


Table 1 Physico-chemical parameters of 113 groundwater samples (1962-2018). The complete data are included in the electronic supplementary material (ESM)

\begin{tabular}{|c|c|c|c|c|c|c|c|c|c|c|c|c|c|c|}
\hline Sample ID & Statistics & $(\mathrm{mg} / \mathrm{L})$ & $(\mu \mathrm{S} / \mathrm{cm})$ & $\begin{array}{l}\text { Temp. } \\
\left({ }^{\circ} \mathrm{C}\right)\end{array}$ & $\begin{array}{l}\mathrm{pH} \\
(-)\end{array}$ & $\begin{array}{l}\mathrm{Ca}^{2+} \\
(\mathrm{mg} / \mathrm{L})\end{array}$ & $\begin{array}{l}\mathrm{Mg}^{2+} \\
(\mathrm{mg} / \mathrm{L})\end{array}$ & $(\mathrm{mg} / \mathrm{L})$ & $\begin{array}{l}\mathrm{K}^{+} \\
(\mathrm{mg} / \mathrm{L})\end{array}$ & $\begin{array}{l}\mathrm{HCO}_{3}^{-} \\
(\mathrm{mg} / \mathrm{L})\end{array}$ & $\begin{array}{l}\mathrm{Cl}^{-} \\
(\mathrm{mg} / \mathrm{L})\end{array}$ & $\begin{array}{l}\mathrm{SO}_{4}^{2} \\
(\mathrm{mg} / \mathrm{L})\end{array}$ & $\begin{array}{l}\mathrm{NO}_{3}^{-} \\
(\mathrm{mg} / \mathrm{L})\end{array}$ & $\begin{array}{l}\mathrm{Br}^{-} \\
(\mathrm{mg} / \mathrm{L})\end{array}$ \\
\hline \multirow{4}{*}{$\begin{array}{l}\text { Hazzir Spring }(N=19) \\
\quad(1989-2018)\end{array}$} & Av & 627 & 842.3 & 16.8 & 7.5 & 90.3 & 24.6 & 40.8 & 11.8 & 289.5 & 68.7 & 36.6 & 64.4 & 1.3 \\
\hline & Max & 750 & 1014.0 & 19.1 & 8.6 & 101.8 & 30.0 & 80.2 & 17.2 & 312.9 & 133.8 & 72.7 & 77.7 & 1.3 \\
\hline & Min & 562 & 760.0 & 13.3 & 7.1 & 81.6 & 19.7 & 29.7 & 7.8 & 263.5 & 53.5 & 17.3 & 35.7 & 1.2 \\
\hline & SD & 47 & 68.0 & 2.5 & 0.4 & 5.1 & 2.9 & 14.2 & 2.0 & 15.5 & 22.1 & 14.0 & 12.4 & 0.1 \\
\hline \multirow{4}{*}{$\begin{array}{l}\text { Baqqouria Spring }(N=19) \\
\quad(1988-2018)\end{array}$} & Av & 475 & 639.8 & 19.9 & 7.6 & 72.5 & 21.2 & 23.6 & 3.7 & 244.2 & 45.7 & 26.8 & 36.7 & 0.3 \\
\hline & Max & 596 & 1004.0 & 21.0 & 8.0 & 86.4 & 56.3 & 42.0 & 5.4 & 274.6 & 87.7 & 47.6 & 64.3 & 0.7 \\
\hline & Min & 407 & 530.0 & 19.2 & 7.2 & 40.1 & 9.5 & 16.1 & 2.0 & 214.7 & 31.6 & 13.4 & 29.8 & 0.2 \\
\hline & SD & 51 & 105.4 & 0.8 & 0.2 & 10.0 & 9.1 & 8.1 & 1.1 & 15.5 & 14.9 & 9.3 & 7.5 & 0.1 \\
\hline \multirow{4}{*}{$\begin{array}{l}\text { Shoreia Spring }(N=20) \\
\quad(1985-2018)\end{array}$} & $\mathrm{Av}$ & 390 & 519.5 & 18.5 & 7.7 & 65.6 & 15.1 & 15.0 & 1.4 & 219.4 & 31.3 & 14.7 & 27.5 & 0.2 \\
\hline & Max & 516 & 853.0 & 20.2 & 8.0 & 81.0 & 22.4 & 30.4 & 4.5 & 265.4 & 62.1 & 29.8 & 34.5 & 0.5 \\
\hline & Min & 330 & 420.0 & 16.5 & 7.2 & 54.1 & 9.6 & 9.2 & 0.0 & 190.9 & 19.9 & 1.9 & 21.0 & 0.1 \\
\hline & SD & 49 & 90.0 & 1.5 & 0.2 & 6.7 & 3.5 & 5.8 & 1.4 & 16.3 & 11.5 & 7.2 & 3.5 & 0.1 \\
\hline \multirow{4}{*}{$\begin{array}{l}\text { Azraq Spring) }(N=19) \\
\quad(1962-2012)\end{array}$} & $\mathrm{Av}$ & 393 & 521.3 & 20.1 & 7.7 & 67.6 & 14.9 & 14.1 & 1.7 & 229.3 & 30.2 & 14.4 & 27.1 & n.a \\
\hline & Max & 587 & 808.0 & 20.1 & 8.2 & 83.4 & 24.8 & 32.2 & 12.1 & 274.5 & 56.4 & 29.8 & 76.0 & 0.0 \\
\hline & Min & 348 & 450.0 & 20.1 & 7.3 & 58.5 & 10.9 & 9.2 & 0.0 & 195.2 & 22.0 & 0.0 & 20.8 & 0.0 \\
\hline & SD & 52 & 92.5 & 0.0 & 0.2 & 6.5 & 3.1 & 6.0 & 3.1 & 16.5 & 8.2 & 9.5 & 12.8 & n.a \\
\hline \multirow{4}{*}{$\begin{array}{l}\text { Jadour Fouq Spring }(N=12) \\
\quad(1991-2018)\end{array}$} & Av & 652 & 881.8 & 19.3 & 7.7 & 89.6 & 24.4 & 47.4 & 14.7 & 264.0 & 76.3 & 35.0 & 99.8 & 0.5 \\
\hline & Max & 767 & 1021.0 & 19.3 & 8.3 & 101.2 & 32.0 & 82.1 & 19.5 & 289.1 & 131.3 & 84.6 & 132.5 & 1.2 \\
\hline & Min & 564 & 796.0 & 19.3 & 7.5 & 84.8 & 17.9 & 32.2 & 11.4 & 250.8 & 56.4 & 5.8 & 63.9 & 0.3 \\
\hline & SD & 60 & 73.6 & 0.0 & 0.2 & 4.9 & 4.2 & 16.7 & 2.1 & 10.5 & 24.7 & 22.6 & 19.9 & 0.3 \\
\hline \multirow{4}{*}{$\begin{array}{l}\text { Jadour Taht Spring }(N=11) \\
\quad(1985-2005)\end{array}$} & Av & 665 & 910.9 & 20.1 & 7.6 & 89.9 & 29.8 & 44.1 & 16.9 & 298.4 & 68.8 & 30.6 & 85.8 & 0.3 \\
\hline & Max & 743 & 1120.0 & 20.1 & 8.5 & 99.0 & 85.5 & 67.6 & 22.3 & 328.8 & 87.7 & 46.1 & 107.0 & 0.5 \\
\hline & Min & 596 & 820.0 & 20.1 & 7.2 & 44.1 & 16.9 & 35.7 & 0.0 & 259.9 & 57.4 & 14.4 & 65.0 & 0.3 \\
\hline & SD & 40 & 78.4 & 0.0 & 0.4 & 14.8 & 18.1 & 9.7 & 5.8 & 16.8 & 9.0 & 8.9 & 11.8 & 0.1 \\
\hline \multirow{4}{*}{$\begin{array}{l}\text { Farkha Spring }(N=7) \\
\quad(1995-2018)\end{array}$} & $\mathrm{Av}$ & 596 & 948.5 & 17.4 & 7.6 & 85.2 & 23.3 & 43.2 & 7.9 & 253.5 & 77.8 & 39.4 & 65.5 & 0.4 \\
\hline & Max & 792 & 1523.0 & 19.3 & 7.8 & 104.5 & 27.8 & 66.1 & 12.9 & 299.0 & 120.6 & 66.3 & 115.0 & 1.0 \\
\hline & Min & 416 & 693.0 & 15.4 & 7.3 & 50.1 & 15.7 & 24.4 & 3.9 & 150.1 & 42.3 & 22.6 & 16.2 & 0.2 \\
\hline & SD & 122 & 277.5 & 1.6 & 0.2 & 15.5 & 3.7 & 15.7 & 2.8 & 45.4 & 29.7 & 17.1 & 27.9 & 0.3 \\
\hline \multirow{4}{*}{$\begin{array}{l}\text { Um Attija well }(N=3) \\
\quad(2012-2018)\end{array}$} & $\mathrm{Av}$ & 622 & 827 & 22.6 & 7.4 & 92.6 & 21.0 & 42.2 & 2.7 & 296.3 & 83.3 & 45.5 & 38.3 & 0.6 \\
\hline & Max & 652 & 853 & 28.0 & 7.6 & 93.3 & 22.1 & 45.6 & 5.0 & 317.3 & 91.4 & 49.2 & 41.8 & 0.8 \\
\hline & Min & 573 & 788 & 16.5 & 7.2 & 91.4 & 19.7 & 36.1 & 1.4 & 272.7 & 73.2 & 40.6 & 35.1 & 0.5 \\
\hline & SD & 35 & 28 & 4.7 & 0.2 & 0.9 & 1.0 & 4.4 & 1.7 & 18.3 & 7.6 & 3.6 & 2.7 & 0.1 \\
\hline \multirow{4}{*}{$\begin{array}{l}\text { Yesidia well }(N=3) \\
\quad(2012-2018)\end{array}$} & $\mathrm{Av}$ & 515 & 790.3 & 19.8 & 7.8 & 71.2 & 25.3 & 24.8 & 3.1 & 292.9 & 50.1 & 26.0 & 21.8 & 0.5 \\
\hline & Max & 534 & 1072.0 & 21.4 & 8.3 & 83.6 & 33.5 & 27.0 & 5.7 & 311.1 & 57.5 & 26.8 & 29.5 & 0.5 \\
\hline & Min & 494 & 638.0 & 17.9 & 7.6 & 56.8 & 20.0 & 20.7 & 1.1 & 277.6 & 36.6 & 25.4 & 6.6 & 0.5 \\
\hline & SD & 16 & 199.4 & 1.5 & 0.3 & 11.0 & 5.9 & 2.9 & 1.9 & 13.8 & 9.5 & 0.6 & 10.7 & 0.0 \\
\hline
\end{tabular}

$\mathrm{Na}^{+}$concentrations due to dissolution of halides during deep groundwater circulations in the surrounding of the lake (Alkhoury et al. 2010). Water from the Yarmouk River is not influenced by much dissolution of halides, as indicated by much lower salt concentrations and $\mathrm{Na}^{+} / \mathrm{Cl}^{-}$ ratios similar to that of precipitation (Alkhoury et al. 2010). Instead, water with relatively high sulfate concentrations might originate from irrigation return flow in the surface catchment area. In contrast, the hydrothermal water from the Mukheiba well (temperature $T=45.1{ }^{\circ} \mathrm{C}$ ) shows low sulfate concentrations due to reducing conditions and degassing of $\mathrm{H}_{2} \mathrm{~S}$. Usually, the imported water (from King Abdullah Canal) should lie within the ternary mixing triangle of these three endmembers; however, higher sulfate concentrations in the King Abdullah Canal samples and the imported water at Zai DWTP indicate additional input 
Table 2 Physico-chemical parameters of 12 surface water, groundwater and wastewater samples from 2017 to 2018. The complete data are included in the ESM

\begin{tabular}{|c|c|c|c|c|c|c|c|c|c|c|c|c|c|c|}
\hline Sample ID & Statistics & $\begin{array}{l}\text { TDS } \\
(\mathrm{mg} / \mathrm{L})\end{array}$ & $\begin{array}{l}\text { Temp. } \\
\left({ }^{\circ} \mathrm{C}\right)\end{array}$ & $\begin{array}{l}\mathrm{pH} \\
(-)\end{array}$ & $\begin{array}{l}\mathrm{EC} \\
(\mu \mathrm{S} / \mathrm{cm})\end{array}$ & $\begin{array}{l}\mathrm{Ca}^{2+} \\
(\mathrm{mg} / \mathrm{L})\end{array}$ & $\begin{array}{l}\mathrm{Mg}^{2+} \\
(\mathrm{mg} / \mathrm{L})\end{array}$ & $\begin{array}{l}\mathrm{Na}^{+} \\
(\mathrm{mg} / \mathrm{L})\end{array}$ & $\begin{array}{l}\mathrm{K}^{+} \\
(\mathrm{mg} / \mathrm{L})\end{array}$ & $\begin{array}{l}\mathrm{HCO}_{3}^{-} \\
(\mathrm{mg} / \mathrm{L})\end{array}$ & $\begin{array}{l}\mathrm{Cl}^{-} \\
(\mathrm{mg} / \mathrm{L})\end{array}$ & $\begin{array}{l}\mathrm{SO}_{4}{ }^{2-} \\
(\mathrm{mg} / \mathrm{L})\end{array}$ & $\begin{array}{l}\mathrm{NO}_{3}^{-} \\
(\mathrm{mg} / \mathrm{L})\end{array}$ & $\begin{array}{l}\mathrm{Br}^{-} \\
(\mathrm{mg} / \mathrm{L})\end{array}$ \\
\hline \multirow[t]{4}{*}{ Water mains $(N=2)(2017)$} & $\mathrm{Av}$ & 681 & 21.3 & 8.2 & 1,177 & 66.5 & 31.0 & 88.3 & 7.2 & 238.0 & 138.9 & 85.9 & 23.6 & 1.1 \\
\hline & Max & 692 & 22.5 & 8.5 & 1,374 & 74.0 & 32.9 & 99.5 & 8.3 & 262.4 & 151.8 & 93.0 & 35.5 & 1.2 \\
\hline & Min & 669 & 20.1 & 7.8 & 980 & 58.9 & 29.1 & 77.0 & 6.2 & 213.6 & 126.0 & 78.8 & 11.6 & 0.9 \\
\hline & SD & 12 & 1.2 & 0.3 & 197 & 7.6 & 1.9 & 11.3 & 1.1 & 24.4 & 12.9 & 7.1 & 12.0 & 0.1 \\
\hline \multirow{4}{*}{$\begin{array}{l}\text { King Abdullah Canal }(N=3) \\
\text { (2017) }\end{array}$} & $\mathrm{Av}$ & 725 & 19.9 & 8.2 & 859 & 50.8 & 33.9 & 110.5 & 10.3 & 266.4 & 141.1 & 104.2 & 5.7 & 1.5 \\
\hline & Max & 757 & 21.1 & 8.5 & 980 & 52.1 & 35.1 & 125.6 & 16.8 & 286.8 & 186.2 & 109.2 & 6.7 & 2.2 \\
\hline & Min & 702 & 18.7 & 7.6 & 638 & 49.2 & 32.4 & 101.2 & 6.8 & 244.1 & 113.0 & 94.3 & 4.2 & 1.0 \\
\hline & SD & 23 & 1.0 & 0.4 & 157 & 1.2 & 1.2 & 10.8 & 4.6 & 17.5 & 32.2 & 7.0 & 1.1 & 0.5 \\
\hline \multirow[t]{4}{*}{ Zai DWTP $(N=2)(2017)$} & Av & 722 & 20.2 & 7.6 & 1,041 & 54.1 & 35.6 & 112.3 & 10.0 & 241.0 & 150.0 & 110.6 & 6.7 & 1.4 \\
\hline & Max & 726 & 20.2 & 7.6 & 1,041 & 55.7 & 36.3 & 117.0 & 12.9 & 244.1 & 157.6 & 120.5 & 6.8 & 1.6 \\
\hline & Min & 717 & 20.2 & 7.6 & 1,041 & 52.5 & 34.8 & 107.6 & 7.1 & 238.0 & 142.3 & 100.7 & 6.6 & 1.2 \\
\hline & SD & - & - & - & - & - & - & - & - & - & - & - & - & - \\
\hline Mukheiba well $(N=1,2017)$ & & 568 & 45.1 & 7.4 & 717 & 59.6 & 19.8 & 49.7 & 6.6 & 353.9 & 65.6 & 12.0 & n.a & 0.5 \\
\hline Yarmouk River $(N=1,2017)$ & & 669 & 16.6 & 7.7 & 664 & 44.8 & 34.0 & 85.8 & 7.8 & 277.6 & 108.0 & 100.2 & 9.6 & 0.7 \\
\hline Lake Tiberias $(N=1,2017)$ & & 834 & 19.1 & 8.3 & 1,074 & 46.5 & 39.7 & 155.4 & 11.0 & 201.4 & 310.1 & 65.6 & 0.3 & 4.5 \\
\hline WWTP As-Salt $(N=1,2017)$ & & 1,176 & 19.4 & 8.6 & 957 & 68.8 & 34.1 & 178.2 & 25.0 & 549.2 & 212.1 & 107.1 & 0.3 & 1.0 \\
\hline WWTP Fuheis $(N=1,2017)$ & & 1,019 & 20.2 & 7.2 & 1,040 & 74.9 & 25.1 & 189.2 & 28.5 & 347.8 & 221.5 & 130.3 & 0.5 & 1.2 \\
\hline
\end{tabular}

Min minimum, Max maximum, Ave arithmetic average, $S D$ standard deviation, $N$ number of samples, $n . a$. not available

Note: Jadour stands for two nearby springs called Jadour Fouq and Jadour Taht, which were combined for reasons of simplicity

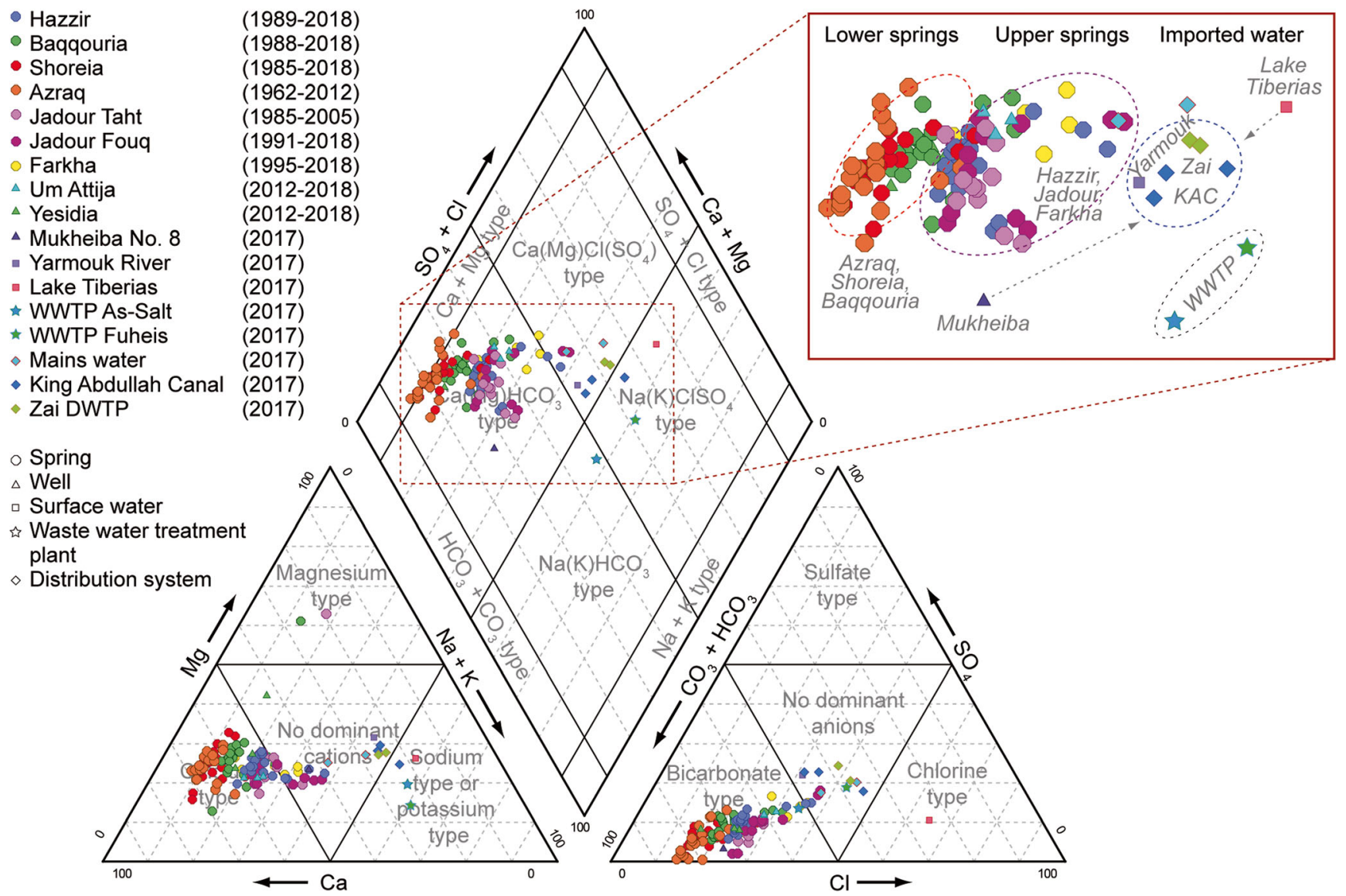

Fig. 5 Piper diagram displaying water samples from 2017 and 2018 of the Wadi Shueib, import water and wastewater complemented with historical data. Generally, groundwater of Wadi Shueib is dominated by calcium and bicarbonate. However, there is a trend towards higher proportions of chloride and sulfate, and sodium and potassium, respectively 


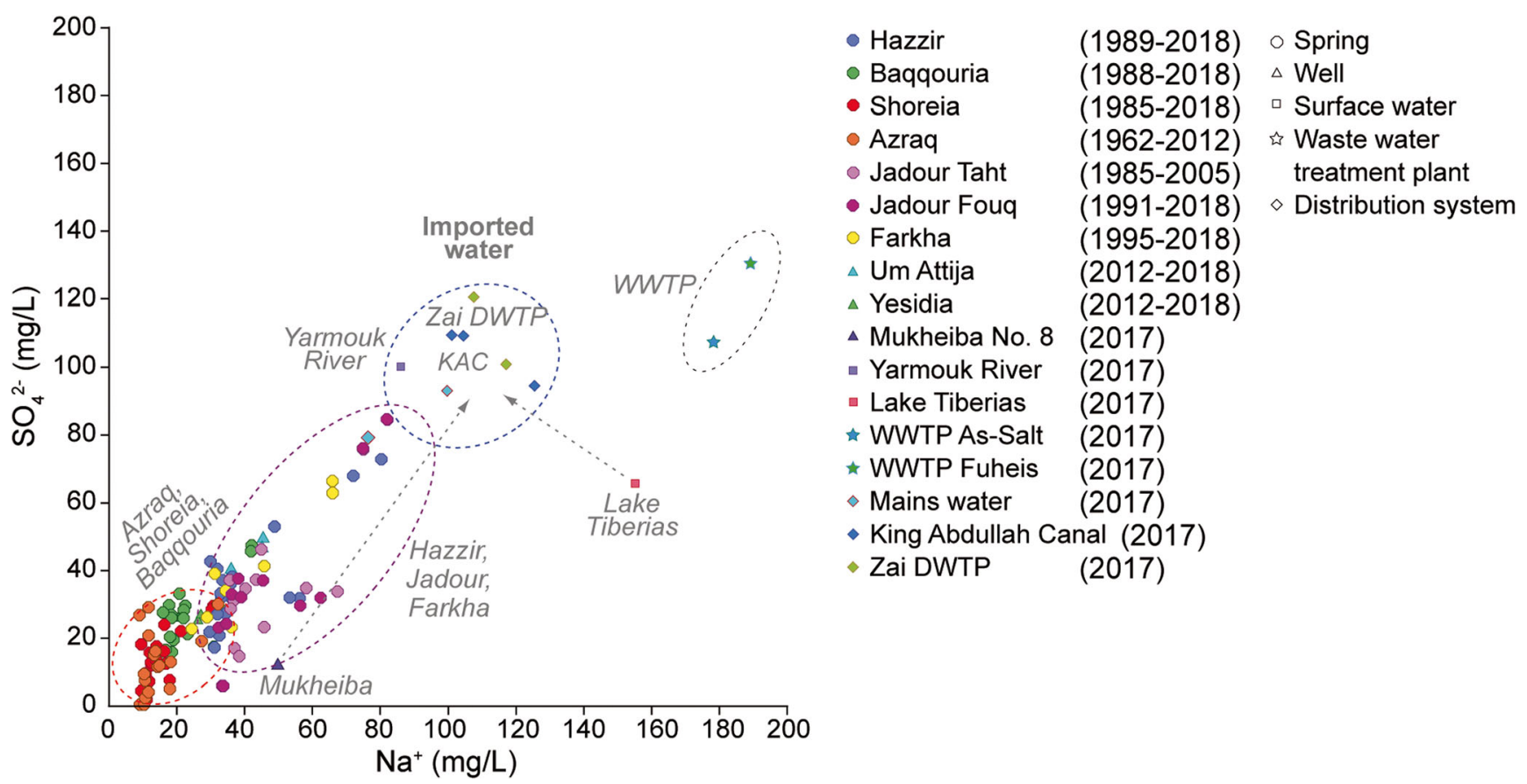

Fig. 6 Scatter plot of $\mathrm{SO}_{4}{ }^{2-}$ vs. $\mathrm{Na}^{+}$showing the hydrochemical genesis from unimpaired groundwater (Shoreia and Yesidia) to a mixed water with imported water and wastewater. Imported water is supplied by the

of sulfate along the King Abdullah Canal, which might be caused by water inlets affected by fertilizers.

To better reveal the mixture between unimpaired groundwater and imported water or wastewater the $\mathrm{Cl}^{-} / \mathrm{Br}^{-}$ratio is taken as indicator for anthropogenic impact (Fig. 7). While meteoric water is characterized by low $\mathrm{Cl}^{-}$concentrations $(3.7-11.6 \mathrm{mg} / \mathrm{L})$ and relatively low $\mathrm{Cl}^{-} / \mathrm{Br}^{-}$ratios $(42-100)$,
King Abdullah Canal (KAC). The imported water from the KAC is a mixture of water from Yarmouk River, Lake Tiberias and Mukheiba wellfield

wastewater exhibited high $\mathrm{Cl}^{-}$concentrations (212-234 mg/ L) and a wide range of $\mathrm{Cl}^{-} / \mathrm{Br}^{-}$ratios (38.5-562). Spring samples show an increase in $\mathrm{Cl}^{-}$concentrations and a slight increase of $\mathrm{Cl}^{-} / \mathrm{Br}^{-}$ratios towards the urban center (upper springs), indicating a stronger impact of wastewater and imported water. High $\mathrm{Cl}^{-}$values are found in the King Abdullah Canal and WWTP samples.

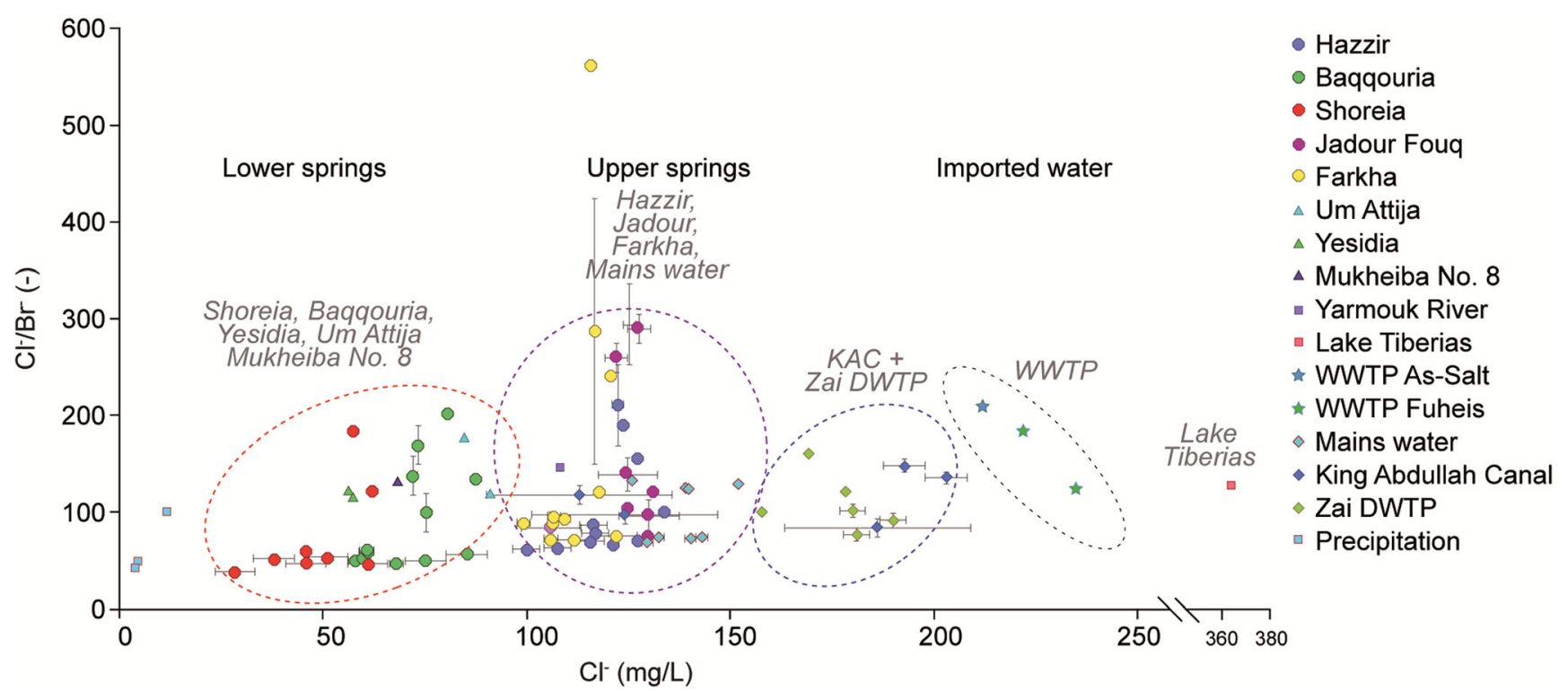

Fig. 7 Chloride versus $\mathrm{Cl}^{-} / \mathrm{Br}^{-}$mass ratio as indicator for anthropogenic impact on groundwater. The samples were taken between 2013 and 2018. The mean values and corresponding error bars are shown, if more than

one sample per sampling campaign were taken. The complete data are included in the ESM 


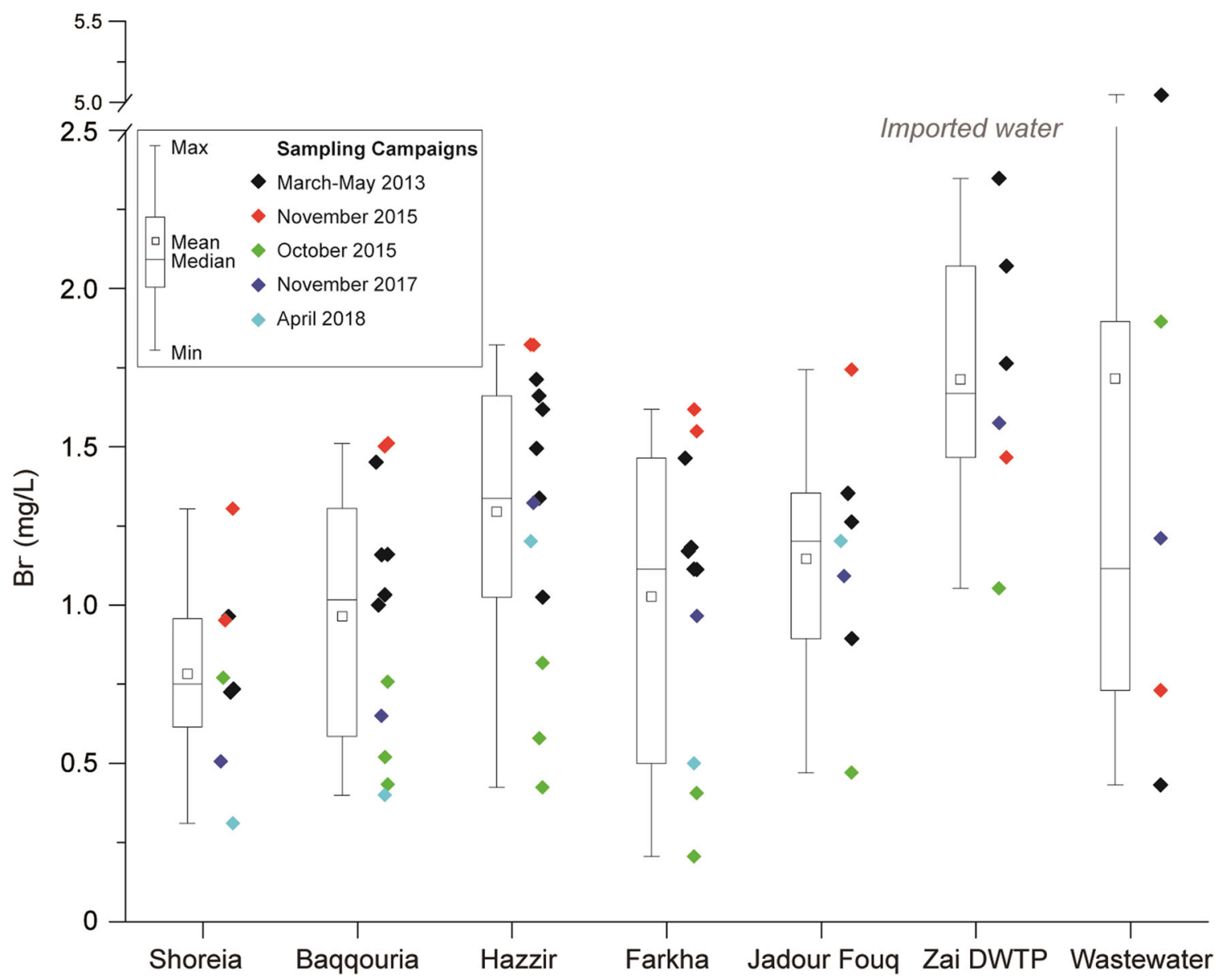

Fig. $8 \mathrm{Br}^{-}$concentrations for the Wadi Shueib springs, the imported water (Zai DWTP) as well as the wastewater for different sampling campaigns and seasons. The seasonal variations of $\mathrm{Br}^{-}$in Zai DWTP are similar to those of the springs

With a temporal resolution of $\mathrm{Br}^{-}$values for summer (April-October) and winter season (November-March), the anthropogenic impact seems more variable, as shown in Fig. 8. This can be explained by varying water proportions of Lake Tiberias on the imported water, because the water contains high bromide concentrations $(4.5 \mathrm{mg} / \mathrm{L})$. Consequently, the second highest $\mathrm{Br}^{-}$concentrations were detected in Zai DWTP (Fig. 8). Because the seasonal variations of $\mathrm{Br}^{-}$in Zai DWTP are similar to those of the springs, groundwater seems more affected by the imported water than by the wastewater. Usually, the proportion of water from Lake Tiberias on the imported water depends on precipitation, because after rainfall more water can be supplied from the Yarmouk River.

In addition to the seasonal trend, a long-term trend of electrical conductivity over five decades from 1975 to 2018 can be observed at the urban affected springs and wells. The electrical conductivity of the upper springs (Jadour, Farkha and Hazzir) increases from about $800 \mu \mathrm{S} / \mathrm{cm}$ in the late 1970s to about $1,000 \mu \mathrm{S} / \mathrm{cm}$ in 2018 , while the electrical conductivity values of the lower springs (Shoreia and Baqqqouria) and Um Attija wells increase from about 500 to $600 \mu \mathrm{S} / \mathrm{cm}$ in the same time.
For a clearer presentation, the long-term trend of the ratio of electrical conductivity to the average electrical conductivity of the respective spring or well is shown in Fig. 9. However, until the 1990s, the electrical conductivity values remained relatively constant. A strong increase in electrical conductivity can be noted from the mid-1990s onwards when Jordan's population doubled from about 4 million in the 1990s to about 10 million today (World Bank 2019). Accordingly, the population in AsSalt grew from 56,000 in 1994 to 115,000 in 2018 (DOS 2019). This had the consequence of an increased impact of the higher mineralized wastewater and imported water on groundwater. The increased electrical conductivity values are mainly attributed to the increase in chloride and sulfate concentrations.

\section{Conclusion}

Anthropogenic impacts on groundwater are manifold in their spatial and temporal occurrence, especially in urbanized karst areas. In addition to short-term and long-term impacts of pollutants, changes in isotope signature and water chemistry can 


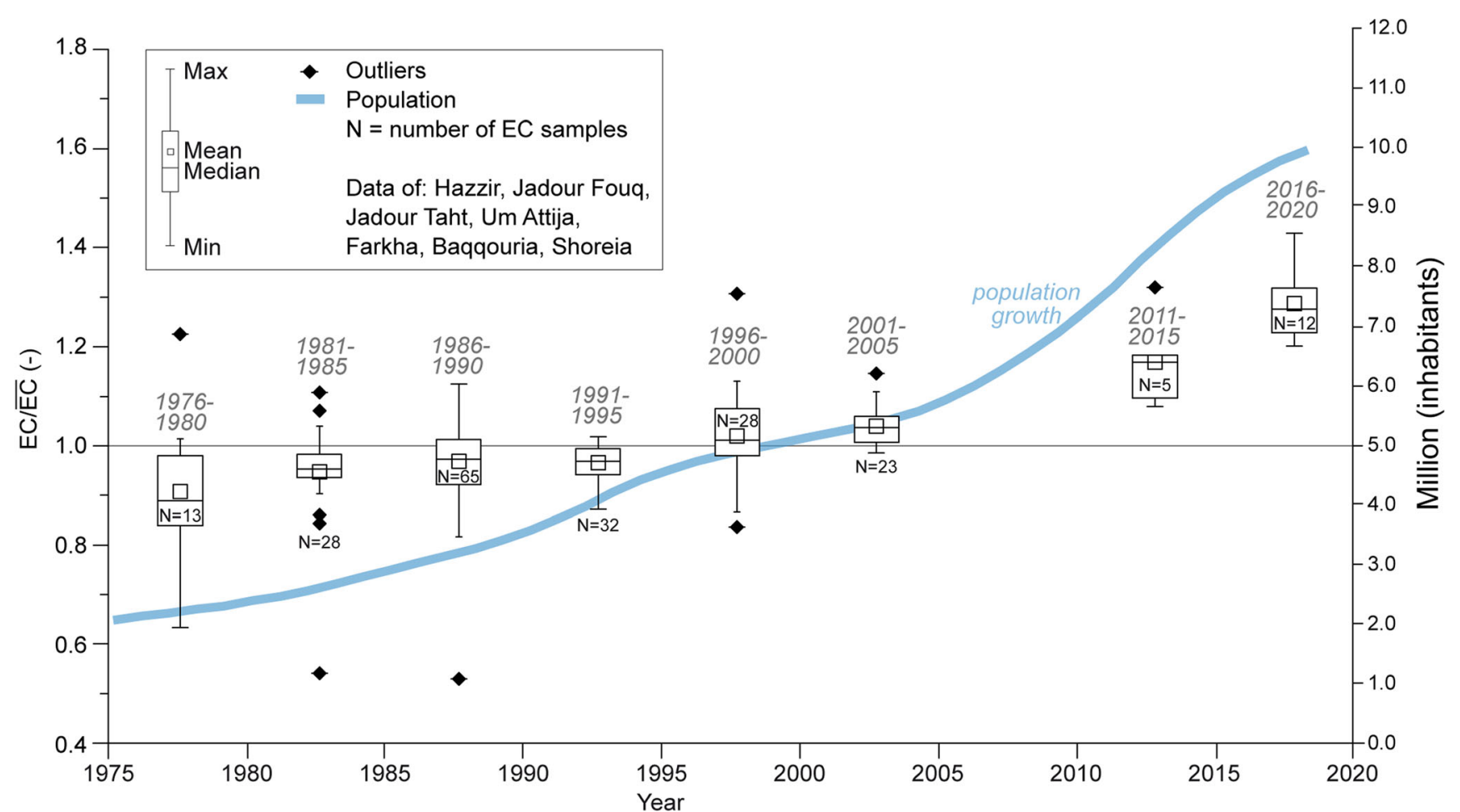

Fig. 9 Box plot of the long-term trend of the ratio of electrical conductivity to the respective average electrical conductivity of the spring or well. The electrical conductivity trend of Hazzir, Jadour Fouq, Jadour That, Farkha, Um Attija, Baqqouria and Shoriea groundwater is

be observed. To document the changes in groundwater chemistry in the Wadi Shueib in Jordan, its major springs, wells, wastewater and imported water were sampled and analyzed in 2017 and 2018 for their major ions, physical parameters and isotopic signature. This also included sampling of the endmembers of the imported water, the Lake Tiberias, the Yarmouk River and the Mukheiba wellfield and along the King Abdullah Canal, which transports the imported water to the Zai drinking-water treatment plant from where it is distributed to the Wadi Shueib. Furthermore, historical hydrochemical data were consulted to understand the longterm impact of the population growth and the associated urbanization in the Wadi Shueib catchment on groundwater resources.

The results showed that imported water cannot be described with a ternary isotopic mixture model as the endmembers Yarmouk River, Lake Tiberias and Mukheiba wellfield lie along a mixing line. However, ternary mixing can be described by the combination of mass ratios of $\mathrm{Cl}^{-} /$ $\mathrm{Br}^{-}$and $\mathrm{Ca}^{2+} / \mathrm{Mg}^{2+}$. It shows that the main contributors to the imported water, at the time of sampling in November 2017, are the Lake Tiberias and the Yarmouk River and with lesser extent the Mukheiba wellfield. Although it was possible to draw a ternary mixing model for the imported water, it is not feasible to present quantitative evaluations based on a single sampling campaign. compared with Jordan's population growth over five decades from 1975 to 2018. The salinity increases particularly from the mid-1990s onwards, accompanied by a rapid increase in population. The complete data are included in the ESM

The comparison of water chemistry data revealed higher sulfate concentrations in the imported water (at the Zai drinking-water treatment plant) than in the endmembers (Lake Tiberias, Yarmouk River and Mukheiba wellfield), which indicates an additional sulfate source along the King Abdullah Canal (e.g. through fertilizers). Similar seasonal variations of $\mathrm{Br}^{-}$in the imported water to those in the Wadi Shueib springs suggested its stronger impact on the local groundwater than on wastewater. However, wastewater does not affect all the springs equally, as only the springs close to the urban center of As-Salt showed slightly increased $\mathrm{Cl}^{-}$ values and $\mathrm{Cl}^{-} / \mathrm{Br}$ - ratios. This reflects the natural heterogeneity and anisotropy of karst aquifers, where preferred flow paths are often very well developed and changes in groundwater quality can be observed to be spatially very different. Over the long-term, from the 1970s to present, a change in water chemistry can be observed in all major springs and wells. While the electrical conductivity remained relatively stable until the 1990s, it increased from the mid-1990s onwards. At the same time a rapidly growing population could be observed in Jordan, which has doubled to almost 10 million since the 1990s, and with it an urbanization of the Wadi Shueib. This has resulted in an overuse of the aquifer and increased impacts from higher mineralized imported water and wastewater as well as in reduced natural groundwater recharge of lower mineralization. 
This study demonstrated the high complexity of urban karst aquifers, in which combined processes of natural and unintended recharge take place through losses of imported water from the supply network and pollution from wastewater. The comprehensive hydrochemical characterization of the Wadi Shueib water resources revealed the need for integrated water resources management concepts for sustainable protection of valuable groundwater resources, and serves as a basis for further research.

Acknowledgements We are grateful to His Excellency Eng. Ali Subah from the Jordanian Ministry of Water and irrigation (MWI) for general support during the research stay in Jordan. We thank Eng. Ahmed Uleimat from the Water Authority Jordan (WAJ) for obtaining permission to enter the border region for water-sampling campaigns and Eng. Israa Zoubi and Eng. Ola Memeh for assistance during fieldwork.

Funding information Open Access funding provided by Projekt DEAL. The Federal Ministry of Education and Research (BMBF) is acknowledged for funding of the SMART-MOVE project (02WM1355).

Open Access This article is licensed under a Creative Commons Attribution 4.0 International License, which permits use, sharing, adaptation, distribution and reproduction in any medium or format, as long as you give appropriate credit to the original author(s) and the source, provide a link to the Creative Commons licence, and indicate if changes were made. The images or other third party material in this article are included in the article's Creative Commons licence, unless indicated otherwise in a credit line to the material. If material is not included in the article's Creative Commons licence and your intended use is not permitted by statutory regulation or exceeds the permitted use, you will need to obtain permission directly from the copyright holder. To view a copy of this licence, visit http://creativecommons.org/licenses/by/4.0/.

\section{References}

Alkhoury W, Ziegmann M, Frimmel FH, Abbt-Braun G, Salameh E (2010) Water quality of the King Abdullah Canal/Jordan: impact on eutrophication and water disinfection. Toxicol Environ Chem 92(5):855-877

Anayah FM, Almasri MN (2009) Trends and occurrences of nitrate in the groundwater of the West Bank, Palestine. Appl Geogr 29(4):588601

Ascott MJ, Gooddy DC, Lapworth DJ, Stuart ME (2016) Estimating the leakage contribution of phosphate dosed drinking water to environmental phosphorus pollution at the national-scale. Sci Total Environ 572:1534-1542

Bajjali W (2012) Spatial variability of environmental isotope and chemical content of precipitation in Jordan and evidence of slight change in climate. Appl Water Sci 2(4):271-283

Barthold FK, Tyralla C, Schneider K, Vaché KB, Frede HG, Breuer L (2011) How many tracers do we need for end member mixing analysis (EMMA)? A sensitivity analysis. Water Resour Res 47(8)

Christophersen N, Hooper RP (1992) Multivariate analysis of stream water chemical data: the use of principal components analysis for the end-member mixing problem. Water Resour Res 28(1):99-107

Davis S, Fabryka-Martin J, Wolfsberg L (2004) Variations of bromide in potable ground water in the United States. Ground Water 42(6/7): 902
DOS (2019) Department of Statistics website. http://dosweb.dos.gov.jo. Accessed November 2019

Doummar J, Geyer T, Baierl M, Nödler K, Licha T, Sauter M (2014) Carbamazepine breakthrough as indicator for specific vulnerability of karst springs: application on the Jeita spring, Lebanon. Appl Geochem 47:150-156

Ford D, Williams P (2007) Karst hydrogeology and geomorphology. Wiley, Chichester, UK

Gat JR, Carmi I (1970) Evolution of the isotopic composition of atmospheric waters in the Mediterranean Sea area. J Geophys Res 75: 3039-3048

Goldscheider N, Chen Z, Broda S, Auler AS, Bakalowicz M, Drew D, Hartmann J, Jiang G, Moosdorf N, Stevanovic Z, Veni G (2019) Global distribution of carbonate rocks and karst water resources. Hydrogeol J. https://link.springer.com/article/10.1007/s10040-02002139-5. Accessed May 2020

Grimmeisen F, Zemann M, Goeppert N, Goldscheider N (2016) Weekly variations of discharge and groundwater quality caused by intermittent water supply in an urbanized karst catchment. J Hydrol 537: $157-170$

Grimmeisen F, Lehmann MF, Liesch T, Goeppert N, Klinger J, Zopfi J, Goldscheider N (2017) Isotopic constraints on water source mixing, network leakage and contamination in an urban groundwater system. Sci Total Environ 583:202-213

Hooper RP (2003) Diagnostic tools for mixing models of stream water chemistry. Water Resour Res 39(3)

Horner KN, Short MA, McPhail DC (2017) Chloride and bromide sources in water: quantitative model use and uncertainty. J Hydrol 549:571-580

ISRAMAR (2019) Israel Oceanographic and Limnological Research Israel Marine Data Center website. https://isramar.ocean.org.il/ isramar2009/DeadSea/LongTerm.aspx. Accessed December 2019

Jurgens BC, Bexfield LM, Eberts SM (2014) A ternary age-mixing model to explain contaminant occurrence in a deep supply well. Groundwater 52(S1):25-39

Karroum M, Elgettafi M, Elmandour A, Wilske C, Himi M, Casas A (2017) Geochemical processes controlling groundwater quality under semi-arid environment: a case study in central Morocco. Sci Total Environ 609:1140-1151

Kuntz D (2003) Soils in the Wadi Shueib catchment area and their protective potential for the Groundwater-Salt area/Hashemite Kingdom of Jordan. Diploma Thesis, University of Karlsruhe, Karlsruhe, Germany

Lax SM, Peterson EW, Van der Hoven SJ (2017) Stream chloride concentrations as a function of land use: a comparison of an agricultural watershed to an urban agricultural watershed. Environ Earth Sci 76: 708

Lerner DN (2002) Identifying and quantifying urban recharge: a review. Hydrogeol J 10(1):143-152

Margane A, Hobler M, Almomani M, Subah A (2002) Contributions to the hydrogeology of northern and central-Jordan. Geologisches Jahrbuch. Bundesanstalt für Geowissenschaften und Rohstoffe und den Staatlichen Geologischen Diensten in der Bundesrepublik Deutschland, Hannover, Germany

Margane A, Subah A, Hamdan I, Hajali Z, Almomani T (2010) Delineation of groundwater protection zones for the springs in Wadi Shuayb. Technical report no. 14, BMZ-No.: 2005.2110.4, Federal Ministry for Economic Cooperation and Development (Bundinisterium für wirtschaftliche Zusammenarbeit und Entwicklung, BMZ), Berlin, 105 pp

Peng TR, Huang CC, Chen JE, Zhan WJ, Chiang LW, Chang LC (2016) Evaluating the relative importance of groundwater recharge sources in a subtropical alluvial plain using tracer-based ternary end member mixing analysis (EMMA). Water Resour Manag 30(11):3861-3878 
Riepl D (2013) Knowledge-based decision support for integrated water resources management with an application for Wadi Shueib. KIT Scientific, Karlsruhe, Germany

Schmidt S, Geyer T, Marei A, Guttman J, Sauter M (2013) Quantification of long-term wastewater impacts on karst groundwater resources in a semi-arid environment by chloride mass balance methods. J Hydrol 502:177-190

Tagar Z, Keinan T, Bromberg G (2007) A seeping timebomb: pollution of the Mountain Aquifer by sewage. In: Water resources in the Middle East. Springer, Heidelberg, Germany, pp 417-426

Tubau I, Vàzquez-Suñé E, Jurado A, Carrera J (2014) Using EMMA and MIX analysis to assess mixing ratios and to identify hydrochemical reactions in groundwater. Sci Total Environ 470:1120-1131

Tubau I, Vázquez-Suñé E, Carrera J, Valhondo C, Criollo R (2017) Quantification of groundwater recharge in urban environments. Sci Total Environ 592:391-402
Vázquez-Suñé E, Carrera J, Tubau I, Sánchez-Vila X, Soler A (2010) An approach to identify urban groundwater recharge. Hydrol Hydrol Earth Syst Sci Discuss 7(2):2543-2576

Werz H (2006) The use of remote sensing imagery for groundwater risk intensity mapping in the Wadi Shueib. PhD Thesis, Universität Karlsruhe, Jordan

World Bank (2019) World Bank website. https://ata.worldbank.org/ country/jordan. Accessed November 2019

Zemann M, Wolf L, Pöschko A, Schmidt N, Sawarieh A, Seder N, Tiehm A, Hötzl H, Goldscheider N (2014) Sources and processes affecting the spatio-temporal distribution of pharmaceuticals and X-ray contrast media in the water resources of the lower Jordan Valley, Jordan. Sci Total Environ 488:100-114

Zemann M, Wolf L, Grimmeisen F, Tiehm A, Klinger J, Hötzl H, Goldscheider N (2015) Tracking changing X-ray contrast media application to an urban-influenced karst aquifer in the Wadi Shueib, Jordan. Environ Pollut 198:133-143 